\title{
Biochar and Bacillus sp. MN54 Assisted Phytoremediation of Diesel and Plant Growth Promotion of Maize in Hydrocarbons Contaminated Soil
}

\author{
Muhammad Hayder Ali ${ }^{1,2}$, Muhammad Imran Khan ${ }^{1, *}$ (D) Safdar Bashir ${ }^{3}{ }^{(1)}$, Muhammad Azam ${ }^{4}$, \\ Muhammad Naveed ${ }^{1}$, Rashad Qadri ${ }^{4}$, Saqib Bashir ${ }^{3}$, Fizza Mehmood ${ }^{1}$, Muhammad Aqeel Shoukat ${ }^{1}$ (D), \\ Yunzhou Li ${ }^{2, *} \mathbb{C}$, Jawaher Alkahtani ${ }^{5}$, Mohamed S. Elshikh ${ }^{5}$ and Yheni Dwiningsih ${ }^{6}$
}

Citation: Ali, M.H.; Khan, M.I.; Bashir, S.; Azam, M.; Naveed, M.; Qadri, R.; Bashir, S.; Mehmood, F.; Shoukat, M.A.; Li, Y.; et al. Biochar and Bacillus sp. MN54 Assisted Phytoremediation of Diesel and Plant Growth Promotion of Maize in Hydrocarbons Contaminated Soil. Agronomy 2021, 11, 1795. https:// doi.org/10.3390/agronomy11091795

Academic Editors: Maria Pilar Bernal and Paula Alvarenga

Received: 30 July 2021

Accepted: 30 August 2021

Published: 8 September 2021

Publisher's Note: MDPI stays neutral with regard to jurisdictional claims in published maps and institutional affiliations.

Copyright: (c) 2021 by the authors. Licensee MDPI, Basel, Switzerland. This article is an open access article distributed under the terms and conditions of the Creative Commons Attribution (CC BY) license (https:// creativecommons.org/licenses/by/ $4.0 /)$.
1 Institute of Soil and Environmental Sciences, University of Agriculture, Faisalabad 38040, Pakistan; hayderali3033@gmail.com (M.H.A.); mnaveeduaf@gmail.com (M.N.); fizzi.meh@gmail.com (F.M.); maqeeltoor@gmail.com (M.A.S.)

2 Department of Plant Pathology, College of Agriculture, Guizhou University, Guiyang 550025, China

3 Department of Soil and Environmental Sciences, Ghazi University, Dera Ghazi Khan 32200, Pakistan; sabashir@gudgk.edu.pk (S.B.); sbashir@gudgk.edu.pk (S.B.)

4 Institute of Horticultural Sciences, University of Agriculture, Faisalabad 38040, Pakistan; azam32jb@yahoo.com (M.A.); rashad.qadri@uaf.edu.pk (R.Q.)

5 Department of Botany and Microbiology, College of Science, King Saud University, Riyadh 11451, Saudi Arabia; jsalkahatani@gmail.com (J.A.); mohamadsolyman@gmail.com (M.S.E.)

6 Department of Crop, Soil and Environmental Sciences, Fayetteville, AR 72701, USA; Sh1133484@gmail.com

* Correspondence: khanimran1173@yahoo.com (M.I.K.); liyunzhou2007@126.com (Y.L.)

Abstract: Contamination by petroleum hydrocarbons (PHs) is a great threat to environment due to the higher persistence and bio-toxicity of PHs. Therefore, removal of PHs from contaminated environment and strategies to reduce their toxic effects on living organisms are crucial for environmental safety and human health. The toxic effects of PHs from the polluted soil can be reduced by the addition of microbes and biochar. In this study, a pot trial was carried out to evaluate the effects of sugarcane bagasse (SB) biochar and Bacillus sp. MN54 addition on phytoremediation of PHs and growth of maize (Zea mays L.) in soil artificially contaminated with diesel. Maize seeds were sown in uncontaminated or contaminated (with PHs) soil, treated with biochar and Bacillus sp. MN54. The results revealed that $\mathrm{PHs}$ showed significant phytotoxicity to maize plants and the application of strain MN54 and biochar greatly reduced the toxic effects of PHs on plants growth and physiology by increasing the nutrients uptake in PHs contaminated soil. Interestingly, the phytotoxicity of PHs on maize plants was further reduced in the co-supplementation of strain MN54 and biochar. Plants physiological (25-48\%) and agronomic (38-47\%) attributes were significantly higher as compared to only PHs contaminated soil in the co-supplementation of strain MN54 and biochar. Similarly, nitrogen $(41 \%)$, phosphorus (43\%) and potassium (37\%) concentrations were also increased in the co-supplementation of strain MN54 and biochar. Furthermore, maize plants successfully phytoremediate a considerable amount of PHs from soil particularly in the presence of strain MN54 and biochar, and this PHs removal was further enhanced in the co-supplementation of strain MN54 and biochar (i.e., $46 \%$ and $77 \%$ of initial PHs were removed in unplanted and planted treatments, respectively). The present results indicate that co-supplementation of biochar and Bacillus sp. MN54 could be effective in enhancing the degradation of PHs and improving plant growth in the hydrocarbons contaminated soil.

Keywords: petroleum hydrocarbons; microorganisms; remediation; bioremediation; PGPR; hyperaccumulation

\section{Introduction}

Contamination by petroleum hydrocarbons (PHs) has become one of the most important environmental issues in the world [1]. Different anthropogenic activities such as 
improper management of underground storage tanks, transportation, industrial processes, accidental spills and mishandling of petroleum products have increased the PHs contamination in the environment $[2,3]$. Furthermore, overexploitation of natural fuel reservoirs to fulfill the demand of rapid growing population has become the prominent sources of PHs contamination all over the world $[4,5]$.

PHs are highly toxic to living organisms and produce toxicity symptoms in plant, microbes, earthworms and other soil biota [6-8]. Some of PHs are known to cause genotoxicity, reproductive toxicity, immuno-toxicity and carcinogenicity in animals and human beings $[9,10]$. Therefore, the removal of PHs from the contaminated environment is crucial for the safety of ecosystem and human health [11].

Among different PHs remediation strategies, phytoremediation is considered the most appropriate, cost-effective and eco-friendly approach [8]. Although several plant species have been shown to be effective for the removal of PHs from contaminated soils [1,12], the improvement in the effectiveness of phytoremediation is still a challenge. It has been well documented those microbial activities and physicochemical properties of soil have a marked impact on the effectiveness of phytoremediation of PHs [13,14]. A vast variety of microbial communities such as fungi, algae and bacteria take part in the complete mineralization of PHs [15]. Bacteria use the carbon from PHs to carry out their reproductive and metabolic mechanisms [16,17]. Several isolated microbes of genera Achromobacter, Bacteroides, Acinetobacter, Microbacterium, Actinobacteria, Pseudomonas, Arthrobacter, Cellulomonas and Azobacter are known to be effective for PHCs degradation $[15,18,19]$. They produce a variety of enzymes to regulate the degradation pathways through different oxidations reactions $[15,18,20]$ and lead to mineralization of $\mathrm{PHs}$ to produce $\mathrm{CO}_{2}$ and $\mathrm{H}_{2} \mathrm{O}[15,21]$. Additionally, the microbial actions such as phosphorus solubilization, ACC-deaminase activity and siderophores production also improve the plants health in the PHs contamination $[19,22,23]$. In return, plant roots release massive amounts of hormones, vitamins, amino acids, organic acids, sugars, mucilage and other related compounds that encourage the microbial activities in the rhizosphere [20,22,24]. Many aromatic fractions of PHs have structural similarity with most of the root exudates, that is why microbial communities use them as a carbon source and increase their biomass coupled with PHs removal from the soil [25-28]. Additionally, the plants in association with microbes show better physical and physiological responses (i.e., seedling emergence, root/shoot biomasses, root/shoot length and chlorophyll contents etc.) and enhance the PHs degradation [13,29,30].

In recent years, the use of biochar as a soil amendment has gained much attention all over the globe [31]. Biochar increases the water holding capacity, porosity, fertility and nutrients retention in soil [32,33] that eventually enhance the plant growth and development [34]. In addition, biochar is considered as a promising material for remediation of organic pollutants including PHs [35] due to the presence of active sites on biochar that adsorb/absorb the pollutants and reduce their bioavailability as presented in Figure S1 [36,37].

Maize (Zea mays L.) is staple food of many countries and used for the production of animal feedstuff and many other maize products such as corn starch and corn syrup, etc. and approximately 4.5 billion people of 94 developing countries fulfilled $30 \%$ of their calories directly from the maize [38]. Globally, maize is grown in more than 165 countries and covers an area of 184 million hectares (mha) with total production of 1016 million tons [39]. After wheat, cotton and rice, maize is the 4th most important crop of Pakistan and is grown over the area of 1.3 and with a total production of $6.3 \mathrm{mha}$ in Pakistan [40]. Maize contributes $0.4 \%$ to gross domestic product (GDP) and $2.2 \%$ agricultural GDP [41]. Other than the economic importance of maize, it is also used as a bio-indicator to examine the PHs contamination, and the selection of maize has numerous advantages over other crops because of its global availability, higher germination rate, fibrous root system and ability to grow in diverse climates [7]. Hence, the main objective of this experiment was to check the impacts of biochar and Bacillus sp. MN54 addition on growth of maize and phytoremediation of PHs in diesel contaminated soil. 


\section{Materials and Methods}

\subsection{Experimental Layout}

A pot study was laid out in the experimental area of Institute of Soil and Environmental Sciences (ISES), University of Agriculture, Faisalabad (UAF), Pakistan. To ensure the homogeneity of soil, the soil was cleaned, aired and passed through a $2 \mathrm{~mm}$ mesh. After that, the soil was spiked with $1 \%(w / v)$ diesel and kept the spiked soil in shades for $30 \mathrm{~d}$ to enhance the interaction between physicochemical properties of soil and diesel [42].

Maize (Zea mays L.), variety Malka-2002, (obtained from Ayoub Agriculture Research institute (AARI),Faisalabad, Pakistan) was chosen as a test plant due to its rapid growth, shallow and deep root system, widespread nature and ability to grow in diverse climates [7]. Then the biochar was added in selected pots at the rate of $1 \%(w / w)$ [16]. The Bacillus sp. MN54, previously identified from the maize rhizosphere and characterized as hydrocarbons degrader and plant growth promoter was taken from the Soil and Environmental Microbiology Lab of ISES, UAF $[23,43]$. The strain also has ability to improve plant growth in various crops under normal or stressed environment as presented in Figure S1 [23,44]. The Bacillus sp. MN54 was grown for $4 \mathrm{~d}$ at $28 \pm 2{ }^{\circ} \mathrm{C}$ in Erlenmeyer flask of $250 \mathrm{~mL}$, containing mineral salt medium (MSM) [45]. The microbial optical density (OD) was determined by using a spectrophotometer, and the OD value was adjusted to 0.5 (i.e., $10^{8}-10^{9} \mathrm{CFU} \mathrm{mL}{ }^{-1}$ ) [23]. Maize seeds were surface-sterilized by following the protocol described by Ali et al. [20]. The surface-sterilized seeds were then immersed in Bacillus sp. MN54 bacterial culture for $2 \mathrm{~h}$ [46]. While, for control treatments, seeds were also soaked in double autoclaved MSM for same period of time.

Each pot, with dimension $26 \times 20 \times 20 \mathrm{~cm}(\mathrm{~L} \times \mathrm{W} \times \mathrm{D})$ was filled with $8 \mathrm{~kg}$ of contaminated or uncontaminated soil. Six maize seeds (untreated or treated) were sown in relevant pots containing uncontaminated or diesel-contaminated soil. After a constant seedling count, only two seedlings were kept in each pot for further experimentation. Recommended doses of $\mathrm{N}$ (i.e., $120 \mathrm{~kg} \mathrm{ha}^{-1}$ as urea), P (i.e., $90 \mathrm{~kg} \mathrm{ha}^{-1}$ as super phosphate) and $\mathrm{K}$ (i.e., $60 \mathrm{~kg} \mathrm{ha}^{-1}$ as potassium sulfate) fertilizers were added in all pots with the ratio 2:1.5:1 [47]. In this experiment, nine different treatments were setup with three replicates and two levels of PHs (0 and 10,000 mg kg-1) in various combinations with Bacillus sp. MN54 and biochar (see Table S1). After $90 \mathrm{~d}$ of sowing, all pots were harvested and the growth as well as physiological parameters of plants and residual PHs contents in soil were determined.

\subsection{Physicochemical Properties of Soil and Biochar}

Sugarcane bagasse (SB) was used as feedstock for production of biochar. Pyrolysis of SB was carried out in muffle furnace (Gallonhop, England) according to the experimental setup described by [48]. SB biochar was produced at $400{ }^{\circ} \mathrm{C}$ with $10^{\circ} \mathrm{C}$ per $60 \mathrm{~s}$ increase in temperature. Numerous physicochemical attributes of soil and biochar were checked before the experiment and are shown in Table S2. The soil texture was determined by using a hydrometer, and the $\mathrm{pH}$, organic matter and electrical conductivity were measured through the procedures given in Azal et al. [23]. While the contents of $\mathrm{P}, \mathrm{K}$, and $\mathrm{N}$ were determined by using standard protocols via spectrophotometer, flame photometer and Kjeldahl apparatus, respectively $[49,50]$.

\subsection{Seedling Emergence, Physiological and Growth Attributes of Maize Plants}

Agronomic attributes such shoot and root lengths, fresh and dry weights of shoot and root were determined and recorded using suitable instruments following standard protocols [20]. Different physiological parameters including photosynthetic rate (A), stomatal conductance $(\mathrm{Gs})$, substomatal conductance $(\mathrm{Ci})$ and transpiration rate $(\mathrm{E})$ were taken using portable infrared gas analyzer (IRGA) (LCA-4, Germany). Chlorophyll contents (SPAD value) were measured by SPAD meter (SPAD-502 Konica, Minolta, Europe), and fluorescence value $(\mathrm{Ft})$, photosynthetically active radiation (PAR), photochemical quantum yield (YII) and electron transport rate (ETR) were checked and recorded by using pho- 
tosynthetic yield analyzer (MINI-PAM-II) (WALZ Messund Regeltechnik) [23,51]. After digestion of plant samples [52], N, P and K contents in plant samples were determined using suitable instruments as described above.

\subsection{Petroleum Hydrocarbons Analysis of Soil}

PHs analysis was conducted following the standard protocols previously described by [20]. Briefly, $50 \mathrm{~g}$ soil sample were collected from each pot and mixed with $100 \mathrm{~mL}$ deionized water and then kept this solution overnight. After $24 \mathrm{~h}$, the solution was gently shaken and kept for an hour before filtration. The filtrate was used to measure the PHs contents by using a portable hydrocarbon analyzer (PHA-100 plus, PETROSENSE ${ }^{\circledR}$, Las Vegas, NV, USA) [20].

\subsection{Statistical Analysis}

Obtained data were analyzed by applying the F-test on different treatment means by using Statistix 8.1, Tallahassee, FL, USA. Variation between means of various treatments at $p \leq 0.05$ were checked by least significant difference (LSD) test by following the completely randomized design (CRD) [53]. The analysis of variance (ANOVA) was done on the subjected data to estimate the variation from mean $(n=3)$ values by the standard error.

\section{Results}

3.1. Effect of Biochar and Bacillus sp. MN54 on Seedling Emergence and Growth of Maize Plants

The results showed that the toxicity of PHs caused significant reduction (i.e., 33\%) in seedling emergence as compared to control (without PHs) (Table 1). The toxic effect of PHs on seedling emergence was reduced by the addition of biochar and/or Bacillus sp. MN54. Approximately, 25\% and 14\% higher seedling emergence was observed in the strain MN54 and biochar amended treatments, respectively than that of untreated soil (with $\mathrm{PHs})$. Moreover, this promotive effect on seedling emergence was further improved by the co-supplementation of strain MN54 and biochar. About 29\% higher seedling emergence was observed in the co-supplementation of strain MN54 and biochar than that of treatment only supplemented with PHs.

Similarly, the PHs contamination showed significant reduction in the root $(38 \%)$ and shoot ( $43 \%)$ lengths, number of leaves $(47 \%)$ and number of spikes $(51 \%)$ per plant, shoot fresh $(36 \%)$ and dry $(45 \%)$ weights, root fresh $(33 \%)$ and dry $(40 \%)$ weights as compared to controls (without PHs) (Table 1). However, toxic impacts of PHs were reduced by the application of biochar and/or Bacillus sp. MN54. Furthermore, the reduced root-to-shoot ratios of maize plants in PHs contaminated soil indicated less negative effects of PHs on root-toshoot ratios (Table 2). The individual application of biochar and strain MN54 increased the root length (37\% and 33\%, respectively) and shoot length ( $40 \%$ and $46 \%$, respectively) as compared to treatment only supplemented with PHs. Additionally, the co-application of biochar and sp. MN54 showed higher root and shoot length (i.e., 47\% 39\%, respectively) as compared to treatment only supplemented with PHs. Likewise, the sole application of biochar and Bacillus sp. MN54 had a promotive effect on number of leaves (11\% and 29\%, respectively) and number of spikes ( $9 \%$ and $26 \%$, respectively) per plant, shoot fresh (i.e., $18 \%$ and $24 \%$, respectively) and dry (i.e., $21 \%$ and $33 \%$, respectively) weights, root fresh (i.e., $18 \%$ and $28 \%$, respectively) and dry (i.e., $18 \%$ and 23 , respectively) weights as compared to treatment only supplemented with PHs (Table 1). Additionally, the reduced root-to-shoot ratios of maize plants in PHs contaminated soil indicated less negative impacts of $\mathrm{PHs}$ on plant shoots than roots (Table 2). Additionally, the co-supplementation of biochar and Bacillus sp. MN54 showed, 40\%, 43\%, 35\%, 39\%, 42\% and 37\% increase in number of leaves, number of spikes, shoot fresh and dry weights and root fresh and dry weights as compared to treatment only supplemented with PHs (with PHs but without biochar and MN54), respectively (Table 1 ). 


\subsection{Effect of Biochar and Bacillus sp. MN54 on Physiology of Maize Plant}

The results revealed that the contamination of PHs induced significant reduction in the physiological attributes of maize plant. Approximately 29\%, 47\%, 53\%, 52\%, 34\%, $37 \%, 29,44 \%$ and $42 \%$ reduction in chlorophyll contents (SPAD value), photosynthetic rate, transpiration rate, stomatal conductance, sub-stomatal conductance, photosynthetically active radiation (PAR), fluorescence yield $(\mathrm{Ft})$, electron transport rate (ETR) and quantum yield (YII) of maize plants, respectively were noticed besides of controls (without PHs) (Table 3). Generally, the PHs contamination showed significant reduction in physiological attributes of maize plants when no amendments (biochar and Bacillus sp. MN54) were used. Significant increases in chlorophyll contents, $(15 \%$ and $18 \%)$ and photosynthetic rates $(9 \%$ and $19 \%)$ was observed in individually applied biochar and Bacillus sp. MN54, respectively as compared to treatment only supplemented with PHs. Interestingly, the cosupplementation of Bacillus sp. MN54 and biochar further increased the chlorophyll content by $26 \%$ and photosynthetic rate by $38 \%$ as compared to treatment only supplemented with PHs (Table 3).

Additionally, the individual use of Bacillus sp. MN54 and biochar significantly enhanced the transpiration rate (i.e., $17 \%$ and $26 \%$ ), stomatal conductance (i.e., $33 \%$ and $45 \%$ ), sub-stomatal conductance (i.e., $17 \%$ and $22 \%$ ), PAR (i.e., $23 \%$ and $29 \%$ ), Ft (i.e., $13 \%$ and $21 \%$ ), YII (i.e., $16 \%$ and $27 \%$ ) and ETR (i.e., $18 \%$ and $22 \%$ ) respectively, was observed than that of treatment only supplemented with PHs. Notably, the co-supplementation of biochar and Bacillus sp. MN54 further enhanced this effect and resulted in $44 \%, 31 \%, 49 \%, 33 \%, 27 \%$, $35 \%$ and $37 \%$ higher transpiration rate, sub-stomatal conductance, stomatal conductance, PAR, Ft, YII, and ETR, respectively as compared to treatment only supplemented with PHs (Table 3).

\subsection{Effect of Biochar and Bacillus sp. MN54 on N, P, and K}

The results showed that the toxicity of PHs caused significant reduction i.e., $56 \%$, $51 \%$ and $42 \%$ in N, P and K contents of maize plant, respectively as compared to control (without PHs). However, the application of biochar increased the N, P and $\mathrm{K}$ value by $14 \%, 23 \%$ and $26 \%$, respectively as compared to treatment only supplemented with PHs. Similarly, the individual use of Bacillus sp. MN54 showed increased contents of N, P and K by $19 \%, 29 \%$ and $28 \%$, respectively as compared to treatment only supplemented with PHs (Figure 1). Notably, the combined application of biochar and Bacillus sp. MN54 showed significant increase in N, P and K contents of maize plant, and the increase was $41 \%, 43 \%$, and $37 \%$ respectively, as compared to treatment only supplemented with PHs (Figure 1).

\subsection{Effect of Biochar and Bacillus sp. MN54 on PHs Removal from Soil}

The results showed that the PHs removal in the planted soil was $25 \%$ higher besides of unplanted soil (Figure 2). Similarly, the individual application of biochar and Bacillus sp. MN54 along with plants, showed 33\% and 38\% more PHs removal than that of their respective unplanted (without plant, but with biochar and/or Bacillus sp. MN54), respectively. Additionally, the co-supplementation of biochar and Bacillus sp. MN54 along with plants enhanced the PHs removal by $58 \%$ as compared to their unplanted (without plant, but with co-supplementation of biochar and Bacillus sp. MN54) (Figure 2). Similarly, the combined application of biochar and Bacillus sp. MN54 showed 77\% overall PHs removal as compared to initially applied concentration of PHs. 
Table 1. Effect of biochar and Bacillus sp. MN54 on agronomic attributes of maize plants grown in diesel contaminated soil.

\begin{tabular}{|c|c|c|c|c|c|c|c|c|c|}
\hline Treatments & SE (\%) & SL (cm) & RL (cm) & NLP & NSP & SFW (g) & SDW (g) & RFW (g) & RDW (g) \\
\hline Control & $100 \pm 0.00 \mathrm{a}$ & $119.7 \pm 1.20 \mathrm{a}$ & $40.0 \pm 2.64 b$ & $15.7 \pm 0.67 \mathrm{a}$ & $13.7 \pm 0.88 \mathrm{a}$ & $104.3 \pm 3.65 \mathrm{a}$ & $30.63 \pm 1.72 \mathrm{a}$ & $17.3 \pm 0.88 \mathrm{ab}$ & $8.47 \pm 0.55 \mathrm{a}$ \\
\hline $\mathrm{PHs}+\mathrm{P}$ & $66.7 \pm 9.53 c$ & $68.3 \pm 4.09 \mathrm{~d}$ & $24.7 \pm 1.76 \mathrm{~d}$ & $8.33 \pm 0.88 \mathrm{~d}$ & $6.67 \pm 0.33 b$ & $66.1 \pm 1.65 c$ & $16.7 \pm 1.20 \mathrm{~d}$ & $11.6 \pm 0.78 c$ & $5.07 \pm 0.26 c$ \\
\hline $\mathrm{M}+\mathrm{PHs}+\mathrm{P}$ & $88.7 \pm 5.67 \mathrm{ab}$ & $107.7 \pm 3.48 b$ & $35.5 \pm 1.89 \mathrm{bc}$ & $11.7 \pm 0.67 \mathrm{bc}$ & $9.00 \pm 0.57 b$ & $87.7 \pm 2.40 \mathrm{~b}$ & $24.9 \pm 1.68 \mathrm{bc}$ & $16.3 \pm 1.45 b$ & $6.57 \pm 0.49 \mathrm{bc}$ \\
\hline $\mathrm{B}+\mathrm{M}+\mathrm{PHs}+\mathrm{P}$ & $94.3 \pm 5.67 \mathrm{ab}$ & $111.7 \pm 3.71 \mathrm{ab}$ & $47.0 \pm 1.57 \mathrm{a}$ & $14.0 \pm 0.57 \mathrm{ab}$ & $11.7 \pm 0.88 \mathrm{a}$ & $101.8 \pm 1.82 \mathrm{a}$ & $27.4 \pm 2.08 \mathrm{ab}$ & $20.2 \pm 1.40 \mathrm{a}$ & $8.07 \pm 0.90 \mathrm{ab}$ \\
\hline
\end{tabular}

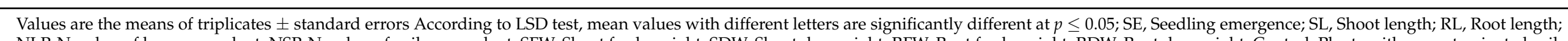

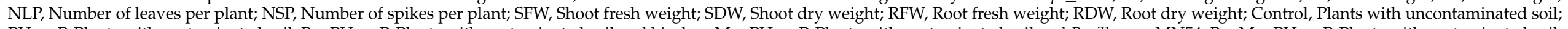

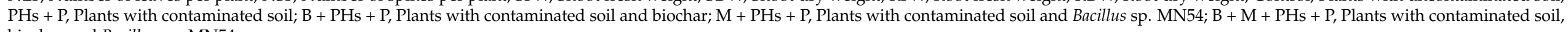
biochar and Bacillus sp. MN54.

Table 2. Root-shoot ratio and specific root length of maize plants after harvesting.

\begin{tabular}{|c|c|c|c|c|}
\hline Treatments & L Root/L Shoot & FW Root/FW Shoot & DW Root/DW Shoot & SRL $\left(\mathrm{m} \mathrm{g}^{-1}\right)$ \\
\hline Control & $0.33 \pm 0.03 b$ & $0.17 \pm 0.01 \mathrm{a}$ & $0.28 \pm 0.03 \mathrm{a}$ & $0.05 \pm 0.035 \mathrm{a}$ \\
\hline $\mathrm{PHs}+\mathrm{P}$ & $0.37 \pm 0.04 \mathrm{ab}$ & $0.18 \pm 0.02 \mathrm{a}$ & $0.31 \pm 0.33 \mathrm{a}$ & $0.05 \pm 0.045 \mathrm{a}$ \\
\hline $\mathrm{M}+\mathrm{PHs}+\mathrm{P}$ & $0.33 \pm 0.02 b$ & $0.19 \pm 0.02 \mathrm{a}$ & $0.26 \pm 0.01 \mathrm{a}$ & $0.06 \pm 0.0069 \mathrm{a}$ \\
\hline $\mathrm{B}+\mathrm{M}+\mathrm{PHs}+\mathrm{P}$ & $0.42 \pm 0.01 \mathrm{a}$ & $0.20 \pm 0.01 \mathrm{a}$ & $0.29 \pm 0.02 \mathrm{a}$ & $0.06 \pm 0.0052 \mathrm{a}$ \\
\hline
\end{tabular}

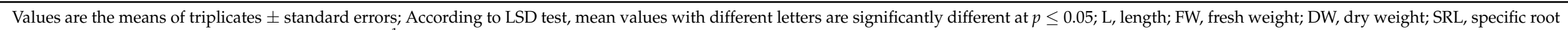

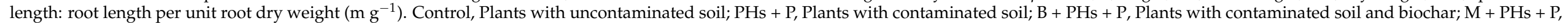

Plants with contaminated soil and Bacillus sp. MN54; B + M + PHs + P, Plants with contaminated soil, biochar and Bacillus sp. MN54. 
Table 3. Effect of biochar and Bacillus sp. MN54 on physiological attributes of maize plants grown in diesel contaminated soil.

\begin{tabular}{|c|c|c|c|c|c|c|c|c|c|}
\hline Treatments & $\begin{array}{c}\text { CPhyl } \\
\left(\mathrm{mg} \mathrm{cm}^{-2}\right)\end{array}$ & 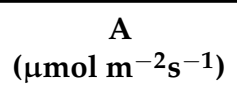 & $\begin{array}{c}E \\
\left(\mathrm{mmol} \mathrm{m}^{-2} \mathrm{~s}^{-1}\right)\end{array}$ & $\begin{array}{c}\mathrm{Gs} \\
\left(\mathrm{mmol} \mathrm{m}^{-2} \mathrm{~s}^{-1}\right)\end{array}$ & $\underset{\left(\mu \mathrm{mol} \mathrm{m} \mathrm{m}^{-2} \mathrm{~s}^{-1}\right)}{\mathrm{Ci}}$ & 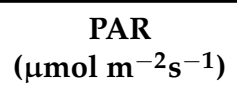 & 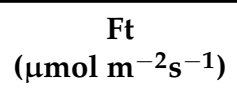 & 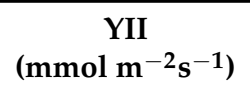 & $\begin{array}{c}\text { ETR } \\
\left(\mathrm{mmol} \mathrm{m}^{-2} \mathrm{~s}^{-1}\right)\end{array}$ \\
\hline Control & $41.8 \pm 1.82 \mathrm{a}$ & $2.72 \pm 0.12 \mathrm{a}$ & $2.53 \pm 0.04 \mathrm{a}$ & $2.21 \pm 0.15 \mathrm{a}$ & $432 \pm 19.5 \mathrm{a}$ & $41.7 \pm 2.09 \mathrm{a}$ & $691 \pm 13.5 \mathrm{a}$ & $0.86 \pm 0.03 \mathrm{a}$ & $28.5 \pm 2.58 \mathrm{a}$ \\
\hline $\mathrm{PHs}+\mathrm{P}$ & $29.4 \pm 2.15 c$ & $1.45 \pm 0.06 c$ & $1.18 \pm 0.04 c$ & $1.04 \pm 0.03 c$ & $283 \pm 8.51 c$ & $26.3 \pm 0.88 c$ & $490 \pm 18.3 d$ & $0.49 \pm 0.04 \mathrm{~d}$ & $16.1 \pm 1.82 c$ \\
\hline $\mathrm{B}+\mathrm{PHs}+\mathrm{P}$ & $34.7 \pm 1.56 b c$ & $1.59 \pm 0.05 c$ & $1.42 \pm 0.59 c$ & $1.57 \pm 0.20 \mathrm{~b}$ & $340 \pm 19.1 b$ & $34.2 \pm 1.21 b$ & $564 \pm 21.2 c$ & $0.59 \pm 0.03 \mathrm{~cd}$ & $19.6 \pm 0.98 b c$ \\
\hline $\mathrm{M}+\mathrm{PHs}+\mathrm{P}$ & $35.8 \pm 1.47 \mathrm{~b}$ & $1.80 \pm 0.15 c$ & $1.60 \pm 0.06 c$ & $1.90 \pm 0.09 \mathrm{ab}$ & $360 \pm 16.6 b$ & $37.1 \pm 1.07 \mathrm{ab}$ & $622 \pm 11.2 b$ & $0.68 \pm 0.02 b c$ & $20.6 \pm 1.54 b c$ \\
\hline $\mathrm{B}+\mathrm{M}+\mathrm{PHs}+\mathrm{P}$ & $39.5 \pm 1.45 \mathrm{ab}$ & $2.32 \pm 0.14 b$ & $2.10 \pm 0.05 b$ & $2.03 \pm 0.04 \mathrm{a}$ & $408 \pm 4.48 \mathrm{a}$ & $39.2 \pm 2.37 \mathrm{ab}$ & $673 \pm 12.8 \mathrm{a}$ & $0.75 \pm 0.03 \mathrm{~b}$ & $25.5 \pm 2.62 \mathrm{ab}$ \\
\hline
\end{tabular}

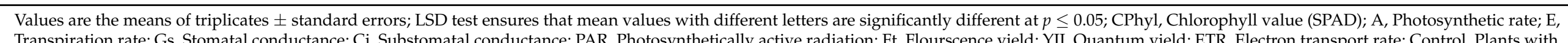

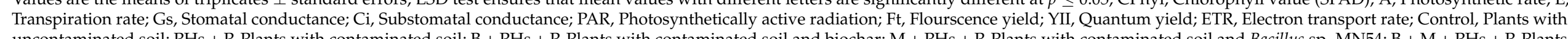

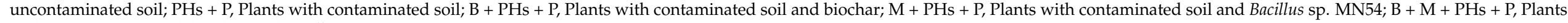
with contaminated soil, biochar and Bacillus sp. MN54 


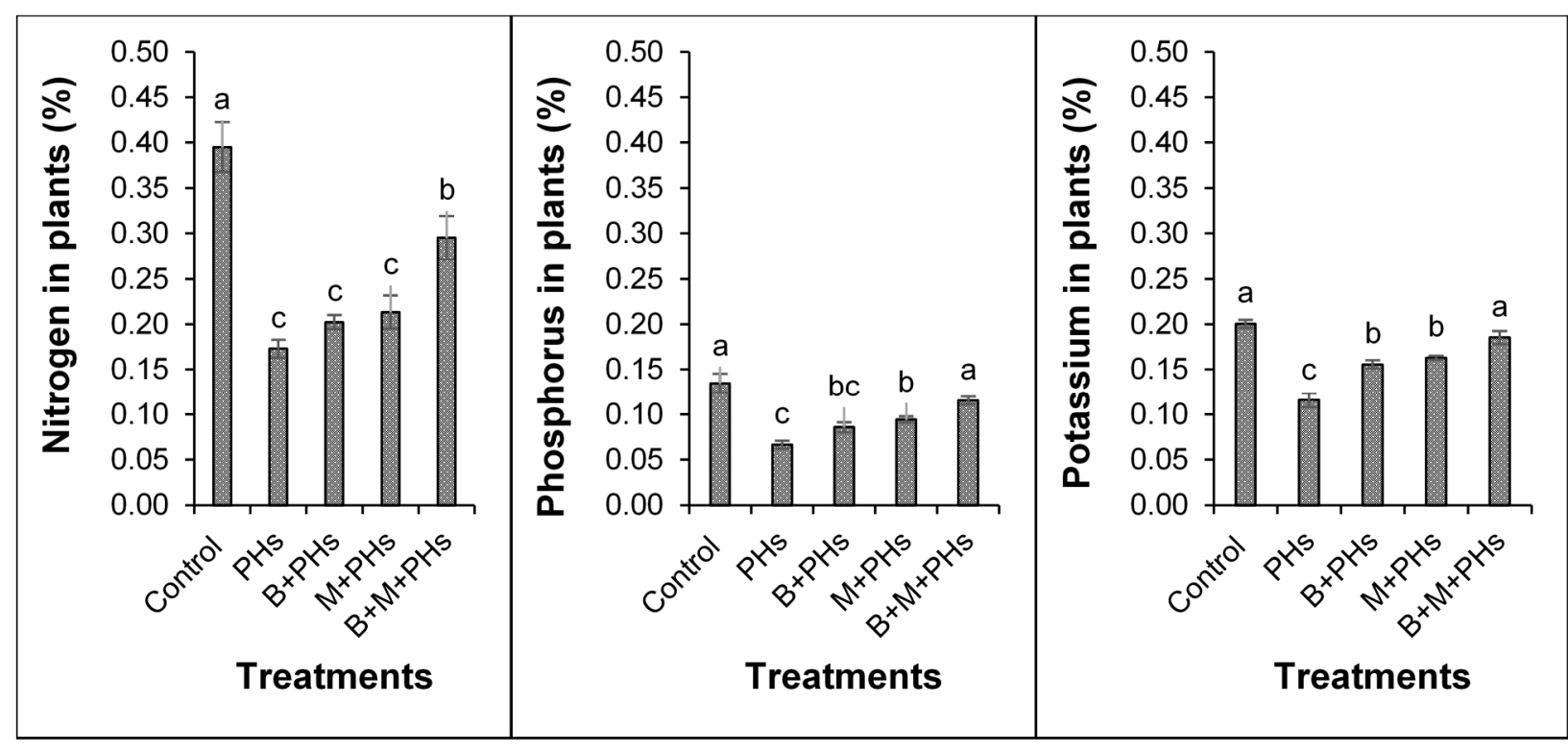

(A)

(B)

(C)

Figure 1. Effect of biochar and Bacillus sp. MN54 on nitrogen (A), phosphorus (B) and potassium (C) contents in plants grown on diesel contaminated soil. Columns and bars represent means and standard errors, respectively of three replicates. Means with different letters are significantly different at $p \leq 0.05$ according to LSD test. (Control, Plants with uncontaminated soil; PHs + P, Plants with contaminated; B + PHs + P, Plants with contaminated soil and biochar; $\mathrm{M}+\mathrm{PHs}+\mathrm{P}, \mathrm{Plants}$ with contaminated soil and Bacillus sp. MN54; B + M + PHs + P, Plants with contaminated soil, biochar and Bacillus sp. MN54).

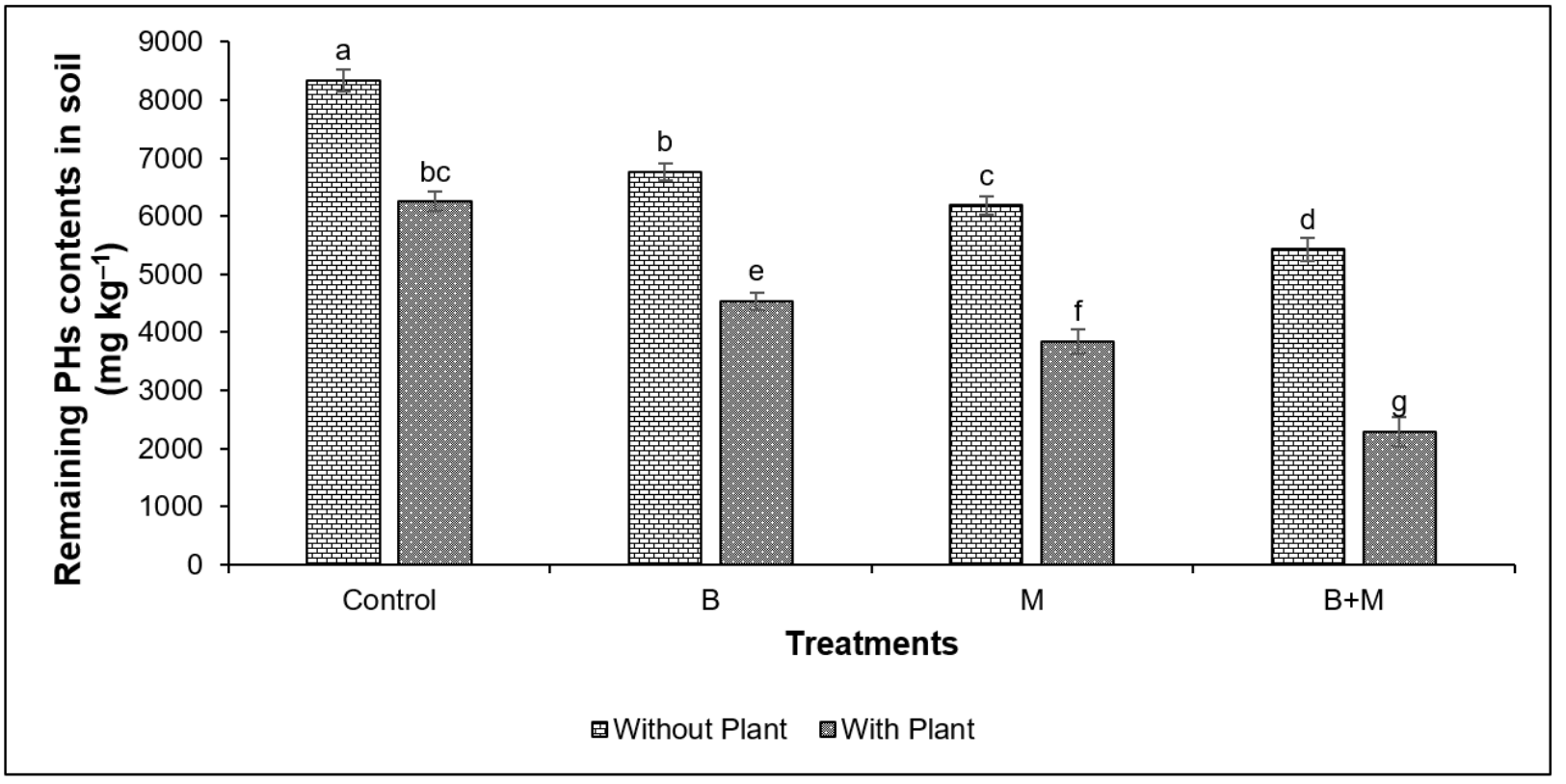

Figure 2. Effect of biochar and Bacillus sp. MN54 on PHs concentrations from diesel contaminated soil. Columns represents the means value and bars represent the standard errors, of triplicates. Means with different letters are significantly different at $p \leq 0.05$ according to LSD test. First two columns represent the control treatments with PHs but with or without plants. The second two columns represent the treatments that contains PHs and biochar but with or without plants. Similarly, third two columns represent the treatments that contain PHs and microbes (Bacillus sp. MN54), but with or without plants. While the last two columns represent the treatments containing PHs, biochar and microbes but with or without plants. 


\section{Discussion}

\subsection{Seedling Emergence and Growth of Maize Plants}

The results showed that the diesel contaminated soil significantly reduced the seedling emergence of maize plants as compared to control. Seedling emergence of maize and other crops such as wheat (Triticum aestivum L.), rye grass (Lolium multiflorum L.), mungbean (Vigna radiata L.) and chickpea (Cicer arientum L.) are often found to be negatively affected by the presence of PHs in soil [54]. The remarkable reduction in seedling emergence of maize in the present study might be due to the susceptibility of the seeds to the volatile fraction of PHs and reduced imbibition of seeds due to hydrophobic conditions induced by PHs $[55,56]$. Notably, the phytotoxic effect of PHs on seedling emergence was greatly reduced in the presence of strain MN54 and biochar, suggesting the significant role of sp. MN54 and biochar addition on seedling emergence [16,34].

Other agronomic attributes such as number of leaves/spikes per plant, root/shoot length and fresh/dry biomass of maize plant were also significantly decreased due to phytotoxic nature of PHs [57]. It might also be due to the fact that plants produce higher amount of ethylene under pollutant stress that cause significant reduction in plant growth [58]. Another possibility of reduced maize growth could be due to the inhibition or reduction in cell expansions and other biochemical processes [56,59]. Interestingly, the phytotoxic effects of PHs on maize growth were greatly reduced in the presence of strain MN54 and biochar, indicating the significant role of microbes and biochar addition on plant growth [60]. Because it has been reported that microbes due to their plant growth promoting characteristics (such as P solubilization, ACC-deaminase activity and siderophore formation) enhance plant growth even under pollutant stress or toxic environment [22,61]. Moreover, the presence of active sites and pore spaces on biochar influences the bioavailability of pollutants (and it might be due to the concentration of) in contaminated soil, and found to be effective in improving plant growth under stress conditions [62,63].

\subsection{Effect of Biochar and Bacillus sp. MN54 on Maize Physiology}

Physiology of maize plant was significantly but negatively influenced in the presence of PHs contents in the soil [60]. The remarkable reduction in the chlorophyll contents, photosynthetic rate, transpiration rate, and stomatal and sub-stomatal conductance of maize plants was observed under contaminant stress [64]. It could be due to the induced contaminant stress that cause photosynthetic pigments reduction, genetic and transcriptional changes, drought stress, reduced leaves turgor pressure and clogging of stomatal openings by impair thalakoid membrane, mitochondria, vacuoles and ribosomes [56,61,65]. Moreover, the phytotoxic effects of PHs on plant physiology were greatly reduced in the presence of bacteria and biochar, suggesting the inevitable role of contminant-tolerant bacteria and biochar addition on plant physiology $[60,61,66]$.

\subsection{Effect of Biochar and Bacillus sp. MN54 on NPK Contents of Plants}

Nutrient contents of maize plants were remarkably decreased by the PHs stress [67]. The significant reduction in the N, P and K contents under PHs contamination could be due to the fluctuation in ion exchange and water holding capacity of soil, precipitation and pore clogging that leads toward reduced mineral release from contaminated soil [8]. Moreover, the phytotoxic effects of PHs on plant nutrients were greatly reduced in the co-supplementation of Bacillus sp. MN54 and biochar, indicating the inevitable role of microbes and biochar addition on nutrient uptake of maize plant $[68,69]$.

\subsection{Effect of Biochar and Bacillus sp. MN54 on Plants and PHs Removal from Soil}

The significant reduction in PHs stress and increased maize growth indicate the interlinked synergistic relationship among plant roots, bacteria and biochar. The PHs removal from soil was increased by the addition of biochar and strain MN54. This could be due to the induced higher rhizospheric effect and/or increased soil porosity and structure for better nutrient uptake $[68,70]$. Roots release several hormones and substances such 
as vitamins, sugars and indole 3-acetic acid that attract the rhizospheric microbes to flourish themselves and degrade aromatic fractions of PHs. It could be happened through various physico-chemical reactions such as oxidation, reduction, dehydrogenation and hydroxylation in the presence of sp. MN54 and biochar [18,71,72]. Additionally, the bacteria act as an environmental cleaner and degrade PHs by utilizing them as carbon energy source and also produce ACC-deaminase to reduce the ethylene stress in plants [34,73].

Strain MN54 have great potential to reclaim the soil by producing several enzymes that degrade the contaminants and promote the maize growth [23]. The PHs removal by the application of biochar could be due to the adsorption capacity of biochar because of (the presence of) several functional groups and active sites for microbial growth $[74,75]$. It could also be due to the improved soil aeration, fertility, ions exchange capacity, water holding capacity, and the presence of macro and micro pores for contaminant sorption that could make the contaminants unavailable for plant uptake [68,76]. Here, we found that the synergistic interactions among plant roots, bacteria and biochar were able to reduce $\mathrm{PHs}$ content in soil and increase the plant growth [34,77].

To our knowledge, this is the first ever study in which the combined effect of Bacillus sp. MN54 and biochar was observed on maize growth and PHs degradation from contaminated soil. Results of this study increase our understandings on plants-microbe relations in PHs contaminated soil and open up new avenues for the researchers to investigate the mechanisms behind this synergistic strategy under PHs stressed environment.

\section{Conclusions}

Present trial was conducted to evaluate the effects of Bacillus sp. MN54 and biochar application on the degradation of PHs and growth of maize under PHs stress. PHs showed apparent phytotoxicity and reduced the root, shoot lengths and fresh dry biomasses in maize plants. Biochar and bacteria are widely used as a soil conditioner. However, in this study, Bacillus sp. MN54 or biochar addition showed reduction in phytotoxicity of PHs on maize plants and therefore, enhancing plants growth in PHs contaminated soil. Furthermore, it was noted that the co-supplementation of Bacillus sp. MN54 and biochar had promising effects on the reclamation of PHs contaminated soil and also improves the growth, physiology and yield of maize plants under PHs stress. The results showed that the co-supplementation of Bacillus sp. MN54 and biochar would be helpful in boosting plant growth under PHs contamination and could act as a suitable choice for phytoremediation investigations.

Supplementary Materials: The following are available online at https://www.mdpi.com/article/ 10.3390/agronomy11091795/s1, Table S1 Detail of treatments used in this study, Table S2 Physicochemical properties of the soil used in the study, Figure S1 Effect of biochar and Bacillus sp. MN54 physical parameters of maize plants grown in hydrocarbons contaminated soil.

Author Contributions: Conceptualization, M.I.K. and S.B. (Safdar Bashir), Y.L.; Data curation, M.H.A., M.A. and M.I.K.; Formal analysis, M.H.A., S.B. (Saqib Bashir), R.Q., M.A.S. and F.M.; Funding acquisition, M.I.K.; Investigation, M.H.A., S.B. (Saqib Bashir) and M.I.K.; Methodology, F.M. and M.H.A.; Project ad-ministration, M.I.K.; Resources, M.I.K., M.N. and S.B. (Safdar Bashir); Software, F.M. and M.H.A.; Supervision, Y.D., J.A., M.S.E., M.I.K.; Writing-original draft, J.A. and M.S.E.; Writing-review and editing, M.I.K., M.H.A., M.A., M.N., S.B. (Safdar Bashir), F.M. and R.Q., M.A.S., Y.L., J.A., M.S.E., Y.D. All authors have read and agreed to the published version of the manuscript.

Funding: This study was partially funded by the Higher Education Commission (HEC) of Pakistan (project number NRPU-7730). This work was also supported by the National Nature Science Foundation (No.32060679) and Projects of Guizhou University (No. Guidapei YU [2019]52 and No. [2017]50). The authors express their appreciation to the researchers supporting project number (RSP-2021/193), King Saud University, Riyadh, Saudi Arabia.

Data Availability Statement: The data presented in this study are available on request from the corresponding author. 
Acknowledgments: The authors express their appreciation to the researchers supporting project number (RSP-2021/193), King Saud University, Riyadh, Saudi Arabia. Authors are grateful to rfan Hussain and all members of Environmental Science Lab (ESL-6), UAF for their assistance and cooperation in this research work.

Conflicts of Interest: The authors declare no conflict of interest.

\section{References}

1. Hatami, E.; Abbaspour, A.; Dorostkar, V. Phytoremediation of a petroleum-polluted soil by native plant species in Lorestan Province, Iran. Environ. Sci. Pollut. Res. 2019, 26, 24323-24330. [CrossRef]

2. Varjani, S.; Upasani, V.N. Influence of abiotic factors, natural attenuation, bioaugmentation and nutrient supplementation on bioremediation of petroleum crude contaminated agricultural soil. J. Environ. Manag. 2019, 245, 358-366. [CrossRef]

3. Adipah, S. Introduction of petroleum hydrocarbons contaminants and its human effects. J. Environ. Sci. Public Health 2019, 3, 1-9. [CrossRef]

4. Qamar, Z.; Khan, S.; Khan, A.; Aamir, M.; Nawab, J.; Waqas, M. Appraisement, source apportionment and health risk of polycyclic aromatic hydrocarbons (PAHs) in vehicle-wash wastewater, Pakistan. Sci. Total Environ. 2017, 605, 106-113. [CrossRef] [PubMed]

5. Hamid, N.; Syed, J.H.; Junaid, M.; Mahmood, A.; Li, J.; Zhang, G.; Malik, R.N. Elucidating the urban levels, sources and health risks of polycyclic aromatic hydrocarbons (PAHs) in Pakistan: Implications for changing energy demand. Sci. Total Environ. 2018, 619, 165-175. [CrossRef] [PubMed]

6. Aisien, F.; Chiadikobi, J.; Aisien, E. Toxicity assessment of some crude oil contaminated soils in the Niger delta. In Advanced Materials Research; Trans Tech Publications Ltd.: Bäch Baech, Switzerland, 2009; pp. 451-455.

7. Khan, M.A.I.; Biswas, B.; Smith, E.; Naidu, R.; Megharaj, M. Toxicity assessment of fresh and weathered petroleum hydrocarbons in contaminated soil-a review. Chemosphere 2018, 212, 755-767. [CrossRef]

8. Logeshwaran, P.; Megharaj, M.; Chadalavada, S.; Bowman, M.; Naidu, R. Petroleum hydrocarbons (PH) in groundwater aquifers: An overview of environmental fate, toxicity, microbial degradation and risk-based remediation approaches. Environ. Technol. Innov. 2018, 10, 175-193. [CrossRef]

9. Varjani, S.J.; Joshi, R.R.; Kumar, P.S.; Srivastava, V.K.; Kumar, V.; Banerjee, C.; Kumar, R.P. Polycyclic aromatic hydrocarbons from petroleum oil industry activities: Effect on human health and their biodegradation. In Waste Bioremediation; Springer: Singapore, 2018; pp. 185-199.

10. Kuppusamy, S.; Maddela, N.R.; Megharaj, M.; Venkateswarlu, K. Impact of total petroleum hydrocarbons on human health. In Total Petroleum Hydrocarbons; Springer: Cham, Switzerland, 2020; pp. 139-165.

11. Alegbeleye, O.O.; Opeolu, B.O.; Jackson, V.A. Polycyclic aromatic hydrocarbons: A critical review of environmental occurrence and bioremediation. Environ. Manag. 2017, 60, 758-783. [CrossRef]

12. Kumar, V.; AlMomin, S.; Al-Aqeel, H.; Al-Salameen, F.; Nair, S.; Shajan, A. Metagenomic analysis of rhizosphere microflora of oil-contaminated soil planted with barley and alfalfa. PLoS ONE 2018, 13, e0202127. [CrossRef]

13. Han, T.; Zhao, Z.; Bartlam, M.; Wang, Y. Combination of biochar amendment and phytoremediation for hydrocarbon removal in petroleum-contaminated soil. Environ. Sci. Pollut. Res. 2016, 23, 21219-21228. [CrossRef]

14. Ye, S.; Zeng, G.; Wu, H.; Zhang, C.; Dai, J.; Liang, J.; Yu, J.; Ren, X.; Yi, H.; Cheng, M. Biological technologies for the remediation of co-contaminated soil. Crit. Rev. Biotechnol. 2017, 37, 1062-1076. [CrossRef]

15. Cui, J.-Q.; He, Q.-S.; Liu, M.-H.; Chen, H.; Sun, M.-B.; Wen, J.-P. Comparative Study on Different Remediation Strategies Applied in Petroleum-Contaminated Soils. Int. J. Environ. Res. Public Health 2020, 17, 1606. [CrossRef] [PubMed]

16. Barati, M.; Bakhtiari, F.; Mowla, D.; Safarzadeh, S. Total petroleum hydrocarbon degradation in contaminated soil as affected by plants growth and biochar. Environ. Earth Sci. 2017, 76, 1-11. [CrossRef]

17. Saini, A.; Bekele, D.N.; Chadalavada, S.; Fang, C.; Naidu, R. A review of electrokinetically enhanced bioremediation technologies for PHs. J. Environ. Sci. 2020, 88, 31-45. [CrossRef] [PubMed]

18. Varjani, S.J. Microbial degradation of petroleum hydrocarbons. Bioresour. Technol. 2017, 223, 277-286. [CrossRef] [PubMed]

19. Wu, T.; Xu, J.; Xie, W.; Yao, Z.; Yang, H.; Sun, C.; Li, X. Pseudomonas aeruginosa L10: A hydrocarbon-degrading, biosurfactantproducing, and plant-growth-promoting endophytic bacterium isolated from a reed (Phragmites australis). Front. Microbiol. 2018, 9, 1087. [CrossRef] [PubMed]

20. Ali, M.H.; Sattar, M.T.; Khan, M.I.; Naveed, M.; Rafique, M.; Alamri, S.; Siddiqui, M.H. Enhanced growth of mungbean and remediation of petroleum hydrocarbons by Enterobacter sp. MN17 and biochar addition in diesel contaminated soil. Appl. Sci. 2020, 10, 8548. [CrossRef]

21. Pugazhendi, A.; Qari, H.; Basahi, J.M.A.-B.; Godon, J.J.; Dhavamani, J. Role of a halothermophilic bacterial consortium for the biodegradation of PAHs and the treatment of petroleum wastewater at extreme conditions. Int. Biodeterior. Biodegrad. 2017, 121, 44-54. [CrossRef]

22. Iqbal, A.; Arshad, M.; Karthikeyan, R.; Gentry, T.J.; Rashid, J.; Ahmed, I.; Schwab, A.P. Diesel degrading bacterial endophytes with plant growth promoting potential isolated from a petroleum storage facility. 3 Biotech 2019, 9, 35. [CrossRef]

23. Afzal, M.J.; Khan, M.I.; Cheema, S.A.; Hussain, S.; Anwar-ul-Haq, M.; Ali, M.H.; Naveed, M. Combined application of Bacillus sp. MN-54 and phosphorus improved growth and reduced lead uptake by maize in the lead-contaminated soil. Environ. Sci. Pollut. Res. 2020, 27, 44528-44539. [CrossRef] 
24. Rafique, H.; Asghar, H.; Zahir, Z.; Shahbaz, M. Evaluation of plant growth promoting bacteria for inducing stress tolerance in plants against petroleum hydrocarbons. Pak. J. Agric. Sci. 2015, 52, 905-914.

25. Guo, M.; Gong, Z.; Miao, R.; Rookes, J.; Cahill, D.; Zhuang, J. Microbial mechanisms controlling the rhizosphere effect of ryegrass on degradation of polycyclic aromatic hydrocarbons in an aged-contaminated agricultural soil. Soil Biol. Biochem. 2017, 113, 130-142. [CrossRef]

26. García-Cruz, N.; Valdivia-Rivera, S.; Narciso-Ortiz, L.; García-Maldonado, J.; Uribe-Flores, M.; Aguirre-Macedo, M.; Lizardi-Jiménez, M. Diesel uptake by an indigenous microbial consortium isolated from sediments of the Southern Gulf of Mexico: Emulsion characterisation. Environ. Pollut. 2019, 250, 849-855. [CrossRef]

27. Garrido-Sanz, D.; Redondo-Nieto, M.; Guirado, M.; Pindado Jiménez, O.; Millán, R.; Martin, M.; Rivilla, R. Metagenomic insights into the bacterial functions of a diesel-degrading consortium for the rhizoremediation of diesel-polluted soil. Genes 2019, 10, 456. [CrossRef]

28. Liu, H.; Gao, H.; Wu, M.; Ma, C.; Wu, J.; Ye, X. Distribution characteristics of bacterial communities and hydrocarbon degradation dynamics during the remediation of petroleum-contaminated soil by enhancing moisture content. Microb. Ecol. 2020, 80, 1-10. [CrossRef] [PubMed]

29. Shahsavari, E.; Adetutu, E.M.; Anderson, P.A.; Ball, A.S. Tolerance of selected plant species to petrogenic hydrocarbons and effect of plant rhizosphere on the microbial removal of hydrocarbons in contaminated soil. Water Air Soil Pollut. 2013, 224, 1-14. [CrossRef]

30. Fatima, K.; Imran, A.; Amin, I.; Khan, Q.M.; Afzal, M. Successful phytoremediation of crude-oil contaminated soil at an oil exploration and production company by plants-bacterial synergism. Int. J. Phytoremediat. 2018, 20, 675-681. [CrossRef] [PubMed]

31. Stefaniuk, M.; Tsang, D.C.; Ok, Y.S.; Oleszczuk, P. A field study of bioavailable polycyclic aromatic hydrocarbons (PAHs) in sewage sludge and biochar amended soils. J. Hazard. Mater. 2018, 349, 27-34. [CrossRef]

32. Mohanty, S.K.; Valenca, R.; Berger, A.W.; Iris, K.; Xiong, X.; Saunders, T.M.; Tsang, D.C. Plenty of room for carbon on the ground: Potential applications of biochar for stormwater treatment. Sci. Total Environ. 2018, 625, 1644-1658. [CrossRef] [PubMed]

33. Hood-Nowotny, R.; Watzinger, A.; Wawra, A.; Soja, G. The impact of biochar incorporation on inorganic nitrogen fertilizer plant uptake; an opportunity for carbon sequestration in temperate agriculture. Geosciences 2018, 8, 420. [CrossRef]

34. Hussain, F.; Hussain, I.; Khan, A.H.A.; Muhammad, Y.S.; Iqbal, M.; Soja, G.; Reichenauer, T.G.; Yousaf, S. Combined application of biochar, compost, and bacterial consortia with Italian ryegrass enhanced phytoremediation of petroleum hydrocarbon contaminated soil. Environ. Exp. Bot. 2018, 153, 80-88. [CrossRef]

35. Dai, Y.; Zhang, N.; Xing, C.; Cui, Q.; Sun, Q. The adsorption, regeneration and engineering applications of biochar for removal organic pollutants: A review. Chemosphere 2019, 223, 12-27. [CrossRef] [PubMed]

36. Dutta, T.; Kwon, E.; Bhattacharya, S.S.; Jeon, B.H.; Deep, A.; Uchimiya, M.; Kim, K.H. Polycyclic aromatic hydrocarbons and volatile organic compounds in biochar and biochar-amended soil: A review. Gcb Bioenergy 2017, 9, 990-1004. [CrossRef]

37. Kołtowski, M.; Hilber, I.; Bucheli, T.D.; Charmas, B.; Skubiszewska-Zięba, J.; Oleszczuk, P. Activated biochars reduce the exposure of polycyclic aromatic hydrocarbons in industrially contaminated soils. Chem. Eng. J. 2017, 310, 33-40. [CrossRef]

38. Kaul, J.; Jain, K.; Olakh, D. An overview on role of yellow maize in food, feed and nutrition security. Int. J. Curr. Microbiol. Appl. Sci. 2019, 8, 3037-3048. [CrossRef]

39. Khan, M.A.; Tariq, M. External Debt and Public Investment: A Case Study of Pakistan. J. Manag. Sci. 2020, 14, 108-117.

40. Nasim, W.; Ahmad, A.; Khaliq, T.; Wajid, A.; Munis, M.F.H.; Chaudhry, H.J.; Ahmad, M.M.M.S.; Hammad, H.M. Effect of organic and inorganic fertilizer on maize hybrids under agro-environmental conditions of Faisalabad-Pakistan. Afr. J. Agric. Res. 2012, 7, 2713-2719.

41. Azam, A.; Shafique, M. Agriculture in Pakistan and its Impact on Economy. Rev. Int. J. Adv. Sci. Technol. 2017, 103, 47-60. [CrossRef]

42. Alaboudi, K.A.; Ahmed, B.; Brodie, G. Effect of biochar on Pb, Cd and Cr availability and maize growth in artificial contaminated soil. Ann. Agric. Sci. 2019, 64, 95-102. [CrossRef]

43. Naveed, M.; Mitter, B.; Yousaf, S.; Pastar, M.; Afzal, M.; Sessitsch, A. The endophyte Enterobacter sp. FD17: A maize growth enhancer selected based on rigorous testing of plant beneficial traits and colonization characteristics. Biol. Fertil. Soils 2014, 50, 249-262. [CrossRef]

44. Khan, M.I.; Afzal, M.J.; Bashir, S.; Naveed, M.; Anum, S.; Cheema, S.A.; Wakeel, A.; Sanaullah, M.; Ali, M.H.; Chen, Z.J.A. Improving Nutrient Uptake, Growth, Yield and Protein Content in Chickpea by the Co-Addition of Phosphorus Fertilizers, Organic Manures, and Bacillus sp. MN-54. Agronomy 2021, 11, 436. [CrossRef]

45. Suja, F.; Rahim, F.; Taha, M.R.; Hambali, N.; Razali, M.R.; Khalid, A.; Hamzah, A. Effects of local microbial bioaugmentation and biostimulation on the bioremediation of total petroleum hydrocarbons (TPH) in crude oil contaminated soil based on laboratory and field observations. Int. Biodeterior. Biodegrad. 2014, 90, 115-122. [CrossRef]

46. Yang, A.; Akhtar, S.S.; Iqbal, S.; Amjad, M.; Naveed, M.; Zahir, Z.A.; Jacobsen, S.E. Enhancing salt tolerance in quinoa by halotolerant bacterial inoculation. Funct. Plant Biol. 2016, 43, 632-642. [CrossRef]

47. Sarwar, G.; Tahir, M.A.; Muhammad, S. Evaluation of dewaxed filter cake press mud for p-release from indigenous rock phosphate and its utilization by maize. Pak. J. Agric. Sci. 2018, 55, 361-366.

48. Sánchez, M.; Lindao, E.; Margaleff, D.; Martínez, O.; Morán, A. Pyrolysis of agricultural residues from rape and sunflowers: Production and characterization of bio-fuels and biochar soil management. J. Anal. Appl. Pyrolysis 2009, 85, 142-144. [CrossRef] 
49. Buondonno, A.; Rashad, A.A.; Coppola, E. Comparing tests for soil fertility. II. The hydrogen peroxide/sulfuric acid treatment as an alternative to the copper/selenium catalyzed digestion process for routine determination of soil nitrogen-kjeldahl. Commun. Soil Sci. Plant Anal. 1995, 26, 1607-1619. [CrossRef]

50. Mc Lean, E.O.; Watson, M.E. Soil measurements of plant-available potassium. Potassium Agric. 1985, 277-308. [CrossRef]

51. Rozier, C.; Hamzaoui, J.; Lemoine, D.; Czarnes, S.; Legendre, L. Field-based assessment of the mechanism of maize yield enhancement by Azospirillum lipoferum CRT1. Sci. Rep. 2017, 7, 1-12. [CrossRef] [PubMed]

52. Estefan, G.; Sommer, R.; Ryan, J. Methods of Soil, Plant, and Water Analysis: A Manual for the West Asia and North Africa Region, 3rd ed.; International Center for Agricultural Research in the Dry Areas (ICARDA): Beirut, Lebanon, 2013.

53. Snedecor, G.W.; Cochran, W.G. Statistical Methods, 7th ed.; Iowa State University Press: Ames, IA, USA, 1980.

54. Grifoni, M.; Rosellini, I.; Angelini, P.; Petruzzelli, G.; Pezzarossa, B. The effect of residual hydrocarbons in soil following oil spillages on the growth of Zea mays plants. Environ. Pollut. 2020, 265, 114950. [CrossRef]

55. Kaur, N.; Erickson, T.E.; Ball, A.S.; Ryan, M.H. A review of germination and early growth as a proxy for plant fitness under petrogenic contamination-Knowledge gaps and recommendations. Sci. Total Environ. 2017, 603, 728-744. [CrossRef]

56. Ambreen, S.; Javed, M.; Hina, M.; Rasul, S.; Zafar, Z.U.; Manzoor, H.; Ogbaga, C.C.; Afzal, M.; Al-Qurainy, F.; Ashraf, M. Influence of sub-lethal crude oil concentration on growth, water relations and photosynthetic capacity of maize (Zea mays L.) plants. Environ. Sci. Pollut. Res. 2016, 23, 18320-18331.

57. Asghar, H.N.; Rafique, H.M.; Khan, M.Y.; Zahir, Z.A. Phytoremediation of light crude oil by maize (Zea mays L.) bio-augmented with plant growth promoting bacteria. Soil Sediment Contam. Int. J. 2017, 26, 749-763. [CrossRef]

58. Baoune, H.; Aparicio, J.D.; Acuña, A.; El Hadj-khelil, A.O.; Sanchez, L.; Polti, M.A.; Alvarez, A. Effectiveness of the Zea maysStreptomyces association for the phytoremediation of petroleum hydrocarbons impacted soils. Ecotoxicol. Environ. Saf. 2019, 184, 109591. [CrossRef] [PubMed]

59. Kudoyarova, G.; Arkhipova, T.; Korshunova, T.; Bakaeva, M.; Loginov, O.; Dodd, I.C. Phytohormone mediation of interactions between plants and non-symbiotic growth promoting bacteria under edaphic stresses. Front. Plant Sci. 2019, 10, 1368. [CrossRef] [PubMed]

60. Hussain, I.; Puschenreiter, M.; Gerhard, S.; Sani, S.G.A.S.; Reichenauer, T.G. Differentiation between physical and chemical effects of oil presence in freshly spiked soil during rhizoremediation trial. Environ. Sci. Pollut. Res. 2019, 26, 18451-18464. [CrossRef] [PubMed]

61. Rajput, V.D.; Gorovtsov, A.V.; Fedorenko, G.M.; Minkina, T.M.; Fedorenko, A.G.; Lysenko, V.S.; Sushkova, S.S.; Mandzhieva, S.S.; Elinson, M.A. The influence of application of biochar and metal-tolerant bacteria in polluted soil on morpho-physiological and anatomical parameters of spring barley. Environ. Geochem. Health 2021, 43, 1477-1489. [CrossRef] [PubMed]

62. Ni, N.; Kong, D.; Wu, W.; He, J.; Shan, Z.; Li, J.; Dou, Y.; Zhang, Y.; Song, Y.; Jiang, X. The role of biochar in reducing the bioavailability and migration of persistent organic pollutants in soil-plant systems: A review. Bull. Environ. Contam. Toxicol. 2020, 104, 157-165. [CrossRef]

63. Burachevskaya, M.; Mandzhieva, S.; Bauer, T.; Minkina, T.; Rajput, V.; Chaplygin, V.; Fedorenko, A.; Chernikova, N.; Zamulina, I.; Kolesnikov, S.; et al. The Effect of Granular Activated Carbon and Biochar on the Availability of $\mathrm{Cu}$ and $\mathrm{Zn}$ to Hordeum sativum Distichum in Contaminated Soil. Plants 2021, 10, 841. [CrossRef]

64. Castro-Mancilla, Y.V.; de la Rosa-Manzano, E.; Castro-Nava, S.; Martínez-Avalos, J.G. Physiological responses of Quercus oleoides (Schltdl \& Cham) to soils contaminated by diesel. Plant Prod. Sci. 2019, 22, 519-529.

65. Cevher-Keskin, B.; Selçukcan-Erol, Ç.; Yüksel, B.; Ertekin, Ö.; Yıldızhan, Y.; Onarıcı, S.; Kulen, O.; Memon, A.R. Comparative transcriptome analysis of Zea mays in response to petroleum hydrocarbon stress. Environ. Sci. Pollut. Res. 2018, 25, 32660-32674. [CrossRef]

66. Gorovtsov, A.V.; Minkina, T.M.; Mandzhieva, S.S.; Perelomov, L.V.; Soja, G.; Zamulina, I.V.; Rajput, V.D.; Sushkova, S.N.; Mohan, D.; Yao, J. The mechanisms of biochar interactions with microorganisms in soil. Environ. Geochem. Health 2019, 42, 1-24. [CrossRef]

67. Zhen, M.; Chen, H.; Liu, Q.; Song, B.; Wang, Y.; Tang, J. Combination of rhamnolipid and biochar in assisting phytoremediation of petroleum hydrocarbon contaminated soil using Spartina anglica. J. Environ. Sci. 2019, 85, 107-118. [CrossRef]

68. Zamani, J.; Hajabbasi, M.A.; Mosaddeghi, M.R.; Soleimani, M.; Shirvani, M.; Schulin, R. Experimentation on degradation of petroleum in contaminated soils in the root zone of maize (Zea Mays L.) inoculated with Piriformospora indica. Soil Sediment Contam. Int. J. 2018, 27, 13-30. [CrossRef]

69. Li, X.; Yao, S.; Bian, Y.; Jiang, X.; Song, Y. The combination of biochar and plant roots improves soil bacterial adaptation to PAH stress: Insights from soil enzymes, microbiome, and metabolome. J. Hazard. Mater. 2020, 400, 123227. [CrossRef]

70. Moubasher, H.; Hegazy, A.; Mohamed, N.; Moustafa, Y.; Kabiel, H.; Hamad, A. Phytoremediation of soils polluted with crude petroleum oil using Bassia scoparia and its associated rhizosphere microorganisms. Int. Biodeterior. Biodegrad. 2015, 98, 113-120. [CrossRef]

71. Peng, S.; Zhou, Q.; Cai, Z.; Zhang, Z. Phytoremediation of petroleum contaminated soils by Mirabilis jalapa L. in a greenhouse plot experiment. J. Hazard. Mater. 2009, 168, 1490-1496. [CrossRef] [PubMed]

72. Abbasian, F.; Lockington, R.; Mallavarapu, M.; Naidu, R. A comprehensive review of aliphatic hydrocarbon biodegradation by bacteria. Appl. Biochem. Biotechnol. 2015, 176, 670-699. [CrossRef] [PubMed] 
73. Liu, W.; Hou, J.; Wang, Q.; Yang, H.; Luo, Y.; Christie, P. Collection and analysis of root exudates of Festuca arundinacea L. and their role in facilitating the phytoremediation of petroleum-contaminated soil. Plant Soil 2015, 389, 109-119. [CrossRef]

74. Smith, K.E.; Thullner, M.; Wick, L.Y.; Harms, H. Sorption to humic acids enhances polycyclic aromatic hydrocarbon biodegradation. Environ. Sci. Technol. 2009, 43, 7205-7211. [CrossRef] [PubMed]

75. Sigmund, G.; Poyntner, C.; Piñar, G.; Kah, M.; Hofmann, T. Influence of compost and biochar on microbial communities and the sorption/degradation of PAHs and NSO-substituted PAHs in contaminated soils. J. Hazard. Mater. 2018, 345, 107-113. [CrossRef] [PubMed]

76. Song, Y.; Li, Y.; Zhang, W.; Wang, F.; Bian, Y.; Boughner, L.A.; Jiang, X. Novel biochar-plant tandem approach for remediating hexachlorobenzene contaminated soils: Proof-of-concept and new insight into the rhizosphere. J. Agric. Food Chem. 2016, 64, 5464-5471. [CrossRef] [PubMed]

77. Xiong, B.; Zhang, Y.; Hou, Y.; Arp, H.P.H.; Reid, B.J.; Cai, C. Enhanced biodegradation of PAHs in historically contaminated soil by M. gilvum inoculated biochar. Chemosphere 2017, 182, 316-324. [CrossRef] [PubMed] 